\title{
Knowledge generation in agricultura research
}

\author{
Geração do conhecimento em pesquisa agropecuária
}

\section{José Roberto de Souza Freire $^{\mathrm{I}}$ Isabel Cristina dos Santos ${ }^{\mathrm{I}}$ Leandro Sauer $^{\mathrm{II}}$}

\section{ABSTRACT}

Over the past decades, Brazilian agriculture has played an important role in the international market, in response to growing global demand for products, services and food security. This achievement was in a large extent powered by the ability to generate knowledge and the actions promoted by science and technology institutes. This article aims to describe the model of knowledge generation in agriculture, assuming that the knowledge cycle is responsible for the capture, identification, selection and share of informal and formal information, through practices in the workplace and outside it, in personal and institutional networks. Based on a comprehensive literature review, this research deals with a multi-case study on three Brazilian science and technology institutes dedicated to agricultural research. Using both, qualitative and quantitative approaches, and collecting data through semistructured interviews applied to seniors researchers, as well as questionnaires answered by 410 scientists holding master's and doctoral degrees in natural sciences. Results indicate the existence of a knowledge generation model in agriculture research focused innovation, whose process starts from capturing ideas on how to solve a problem using the technological competence developed, through formal research projects.

Key words: knowledge, generation, open innovation, institutes of science and technology, agricultural research.

\section{RESUMO}

No decorrer das últimas décadas, a agropecuária brasileira tem desempenhado um papel importante no mercado internacional, em resposta às crescentes demandas globais por produtos, serviços e segurança alimentar. Essa conquista foi estimulada, em grande parte, pela capacidade de geração de conhecimento e ações promovidas pelos institutos de ciência e tecnologia. Este artigo visa a descrever o modelo de geração do conhecimento na pesquisa agropecuária, assumindo que o ciclo do conhecimento inclui a captura, internalização e compartilhamento do conhecimento, mediante práticas informais e formais no ambiente de trabalho e nas redes de relacionamento, pessoais e institucionais. Precedida por ampla revisão teórica, a pesquisa é baseada em um estudo multicasos em três institutos de ciência e tecnologia, com foco na pesquisa agropecuária, com abordagem quali-quantitativa, instrumentalizada por entrevistas semiestruturadas aos pesquisadores seniores e aplicação de questionários em uma amostra de 410 pesquisadores com título de mestres e doutores em áreas relacionadas à pesquisa agropecuária. Os resultados indicam um modelo de geração do conhecimento em institutos de pesquisa agropecuária voltados à inovação, que tem origem na captura de ideias sobre como solucionar um problema com uso da competência tecnológica desenvolvida, por meio da elaboração do projeto de pesquisa.

Palavras-chave: geração do conhecimento, inovação aberta, institutos de ciência e tecnologia, pesquisa agropecuária.

\section{INTRODUCTION}

The importance of this study lays in the perspective of better understanding the model of knowledge generation and technological development, especially regarding companies that invest in innovation on agribusiness. This is of utmost importance in the context of developing economies, because to reach the technological frontier, they need to speed up the technology accumulation process until they reach a generally faster rate than that seen in companies of highly industrialized economies, as mentioned by BELL \& PAVITT (1995).

IPrograma de Pós-graduação em Administração, Universidade Municipal de São Caetano do Sul (USCS), Rua Santo Antônio, 50, 09521-160, São Caetano do Sul, SP, Brasil. E-mail: joserobertofreire@gmail.com. "Corresponding author.

IIPrograma de Pós-graduação em Administração, Universidade Federal de Mato Grosso do Sul (UFMT), Campo Grande, MT, Brasil. 
The literature on knowledge generation in agriculture is rather scarce in relation to knowledge management in the manufacturing sector. It can be highlighted the study of ROSSETTI (2009), in which the perspective of interdisciplinarity and interaction of knowledge is focused on agricultural research projects. Over the past decades, Brazilian agriculture has played an important role in the world market, in response to growing global demand for products, services and food security. The capacity to generate knowledge as well as initiatives promoted by science and technology institutes and universities are largely responsible for this achievement.

BARROS (2014), based on data obtained from the World Trade Organization - WTO, reported that in 1990 the Brazilian agricultural surplus was of USD 7 billion. The author points out that by 2011 this number had increased tenfold, reaching USD 73 billion, and in 2013 this surplus reached USD 83 billion. It is estimated that to a large extent, this growth can be related to scientific and technological development applied to the agricultural sector through efforts directed to research, development and innovation-RD\&I in Science and Technology Institutes-STI for agribusiness.

In the scope of these discussions on innovation in agribusiness, knowledge cycle is comprised by the steps: knowledge generation, saving, distribution, application and protection. The following question arises: how do STIs generate new knowledge in the agricultural sector? In this regard, this study is limited only to the first stage, which is the generation of knowledge. The result will be restricted to the institutions surveyed-three Brazilian public institutes of science and technology, internationally recognized in agricultural research. The methodology adopted was multi-cases study.

The knowledge cycle resulting in technology and innovation, particularly in STIs, assumes the understanding of the research object in the context of the organisms that comprise it and the mechanisms of their intrinsic relations: knowledge, creation of knowledge, farmers, organizational structure, research funding and environment.

\section{Knowledge generation}

The theoretical contribution of this research brings together some of the most quoted authors in the academic literature, who address knowledge cycle, such as NONAKA \&TAKEUCHI (1997); DALKIR (2005); NONAKA \& TAKEUCHI (2008). The literature review aims to identify existing models and systems for knowledge generation as well as the distinction between them. Additionally, this investigation aims to identify some general model adaptable to other agricultural research institutions or, perhaps, identifying elements or characteristics that could be incorporated into the scope of this work. However, only few studies focused on knowledge generation in agricultural research, science and technology institutes were found.

For the authors above, knowledge creation happens exactly in a conversion processes of tacit to explicit knowledge and vice-versa. They also argue that the tacit and explicit knowledge are not totally separated, but they complement each other, interacting and interchanging in human creative activities. From that, the importance of an in-person or virtual environment for information exchange in knowledge generation.

To better explain the cycle of knowledge, TAKEUCHI \& NONAKA (2008) employ the term "spiral of knowledge generation", which emerges when the interaction between tacit and explicit knowledge is dynamically increased from a lower ontological level to higher levels, which does not generate itself, but is based on intention to achieve preset organizational goals.

The main point of this theory is how to emerge from this spiral of knowledge generation. The same authors postulate four different ways of knowledge conversion, when the tacit and explicit interact with one another: socialization, externalization, combination, internalization, which interact with each other and constitute the SECI Model.

Socialization is tacit knowledge to tacit, that is, communication between people in a process of sharing their experiences. It may be in a formal way, by working organization, or informal, between people. This interaction requires a healthy working relationship and mutual trust among participants.

Externalization is the tacit knowledge to explicit, i.e. a formal interaction process of verbal communication of experience. It can be at distance or in-presence, like a seminar, a lecture, video conferencing or a written process like articles, brochures or books. Currently, information technology tools have helped a lot in this process, especially in formation of new concepts network.

Internalization is the explicit knowledge to tacit, being a continued learning that emphasizes certain models/standards. It may be through a colleague, a facilitator or teacher, or even by a self-improvement process (learning by doing); one interacts through experiences, sharing and socialization in a systematized process that becomes part of the institution's culture. 
Combination is the explicit knowledge to explicit. It is the formality of communication for information in the systematization of existing concepts into a new knowledge system. It is the process of knowledge creation which crystallizes itself. It is encoded and incorporated according to the organization's culture.

Briefly, socialization begins with the creation of a "field" of interaction. This field facilitates sharing experiences and members' mental models. Externalization is promoted by "dialogue or collective reflection" so that team members articulate hidden tacit knowledge that otherwise would be difficult to be communicated. The combination is generated by the juxtaposition of the newly created knowledge and existing knowledge in other areas of knowledge in a "network", crystallizing them into a new product, service or management system. Finally, the "learning by doing" leads knowledge towards internalization (NONAKA et al., 2011).

The contents of knowledge generated by each of the knowledge conversion modes is obviously different. Socialization creates what can be called "shared knowledge" like shared mental models or technical skills. The contents of knowledge interact among themselves in the knowledge cycle.

DALKIR (2005) points out that a good definition of knowledge has to incorporate both, capture and saving of the knowledge perspective. For this author, knowledge cycle is the deliberate and systematic coordination of people, technologies, processes and organizational structure, adding value through reuse and innovation, what shows that the author refers to knowledge management and not its generation.

DALKIR (2005) also summarizes these concepts as follows: the basic goal of knowledge management is to leverage knowledge for the organization's benefit. Some manager's reasons are obvious: loss of skilled people, pressures to avoid "reinventing the wheel", pressures for the organization to develop innovation over processes, as well as products and services in risk management, and faster rates of new knowledge development. This leads organizations towards creation of appropriate environment for knowledge generation.

In fact, in its nature, knowledge is different from the information and physical resources, and, unless one understands the essential nature of knowledge, on cannot share it or use it, and, above all, effectively create it (NONAKA et al., 2011). The most critical element of knowledge generation is the conceptualization of a vision for the company's strategy, which should be developed, as well as operating this knowledge. The authors NONAKA et al. (2011) advise that the manager should understand knowledge, primarily as a process, even when knowledge seems to acquire a concrete or substantial form as a product.

The discussion on the approaches for agricultural knowledge and practices in RD\&I presented by ROSSETTI (2009) were based in a study on the knowledge cycle in agriculture. It states that the diversity of knowledge areas in agricultural research institutions has unique characteristics that distinguish them from other organizations. These studies focus on the involvement of interdisciplinary and multidisciplinary teams from research projects.

Although ROSSETI (2009) had not referred to the term "open innovation" proposed by CHESBROUGH (2012), his studies describe the need to allow the ideas flow to both, inside and outside the institution. In the open innovation model, projects and ideas go beyond the boundaries of the enterprise, and they are developed until the projects reach the market.

This approach is based on a different knowledge scenario, with a logic about the sources and uses of ideas, meaning that ideas may arise from inside or outside the institution. The availability and quality of these external ideas change the logic that leads to the formation of R\&D knowledge (CHESBROUGH, 2012). Knowledge is not restricted to STIs or to universities, but it is present in many partners and collaborators. As well as other sectors of society; important is how to capture this knowledge and to transform it into technological innovation for society in an increasingly demanding and competitive market.

The assumption of open innovation, created by CHESBROUGH (2012) suggests that local scientists should not only include the generation of internal knowledge, but also the mediation of knowledge, besides socializing this knowledge to in- and outside of companies. In this new role, knowledge internally generated can be as useful as the knowledge generated externally.

\section{MATERIALS AND METHODS}

This research was carried out from July to November 2014, in three science and technology institutes focused on research and development in agriculture: Agronomic Institute of Paraná - IAPAR; Institute of Animal Science - IZ and Embrapa.

Four steps were followed when carrying out the research, as proposed by YIN (2005) and 
GIL (2010) for multiple case study. Following authors recommendation, the procedures od data collection are outlined as documentary research since we accessed institute's directive plan, internal publications, brochures, technical communication; semi-structured interviews held in-person with scientists from the three STIs, during which it was possible to register perceptions developed from direct observations in loco; and application of a previously tested and validated questionnaire using an online survey in the three STIs.

At Embrapa, interviews were carried out only at the Beef Cattle Research Center, while the questionnaires were intentionally sent to centers located in each of the five Brazilian regions, given that the company operates throughout the whole country.

There were 29 interviews in the three institutes with authorized recording of approximately 50 minutes for each interview. It was sent a total of 659 questionnaires with a feedback of 410 high qualified participants, all of them holders of master's degree or doctorate's degree.

Semi-structured interviews aimed to identify the following: how the need for new knowledge arises; institutional criteria for the submission of an idea; how does knowledge sharing happens; events related to knowledge cycle, formal and informal, promoted in the institution; if the ideas are new or opportunities arise from other technologies or farmer's demand or call for applications; facilitating/troubling factors that arise in the development of research projects.

Processing of data collected in questionnaires was based on exploratory factor analysis (HAIR et al., 2009), using IBM-SPSS statistical analysis software. Criterion was the total explained variance and unit root, aiming to identify the optimal number of factors that can be extracted. Also statistical descriptive analysis was used, showing the frequency of responses, means and standard deviations. Data collected in the interviews were subjected to content analysis within the following categories: capture, sharing and internalization, considering the knowledge cycle from the theoretical/conceptual references of NONAKA \& TAKEUCHI (1997).

\section{RESULTS AND DISCUSSION}

Respondents emphasized that many ideas of informal discussions, which are nonetheless an exchange of information and knowledge, occur in a moment of relaxation, in the corridors or coffee breaks. As shown by NONAKA et al. (2011), New knowledge emerge of the relationship between professionals and the interactions between the institutions: businesses, universities and research centers. And the sharing of information often occur in work environments, in contact with customers and suppliers, giving shape and substance to the intellectual capital and strengthening the capacities of organizations to deal with the challenges and competitiveness.

In short, the analysis comprehends the agricultural knowledge cycle model in STI shown in figure 1. Cycle follows this path: identification and selection of an idea that can generate a product or service; exchange ideas with colleagues; analysis of proposed priorities in R\&D projects; internalization of discussion on research group; project design and submission to the Scientific Committee.

A factor analysis was carried out for each of the three dimensions analyzed - knowledge capture; internalization and sharing of knowledgebased on the application of explained variance criterions. However, before factor analysis, KaiserMeyer-Olkin tests (KMO) were carried out, which evaluates the sampling suitability measure, indicating if the correlation between the pairs of variables can be explained by a combination of other variables (factors). According to AAKER et al. (2007), only to values above 0.6 the use of Factor Analysis is recommended. Also the Bartlett's test of sphericity (Bartlett's test) was used, testing the hypothesis of the correlation matrix being the identity matrix, i.e. there are no correlations among the variables studied. It is noteworthy that in this test, the null hypothesis is that there is no correlation between the variables, therefore, low p-values (e.g. less than 0.05) indicated that is possible to apply the factor analysis.

For the first dimension, knowledge capture, we had $\mathrm{KMO}=0.881$, p-value (Bartlett) $<0.0001$ and variance explained for the first seven factors $=68.3 \%$, nominated as opportunities to generate ideas. For the second dimension, internalization of knowledge, values were: $\mathrm{KMO}=0.848$; $\mathrm{p}$-value (Bartlett) $<0.0001$ and variance explained for the first four factors $=64.7 \%$, nominated as applicability and development of ideas. In the case of the third dimension, sharing of knowledge, values were: $\mathrm{KMO}=0.827$; p-value (Bartlett) $<0.0001$ and variance explained for the first four factors $=9.2 \%$, nominated as institutionalization of ideas.

The application of exploratory factor analysis confirmed the existence of the three 


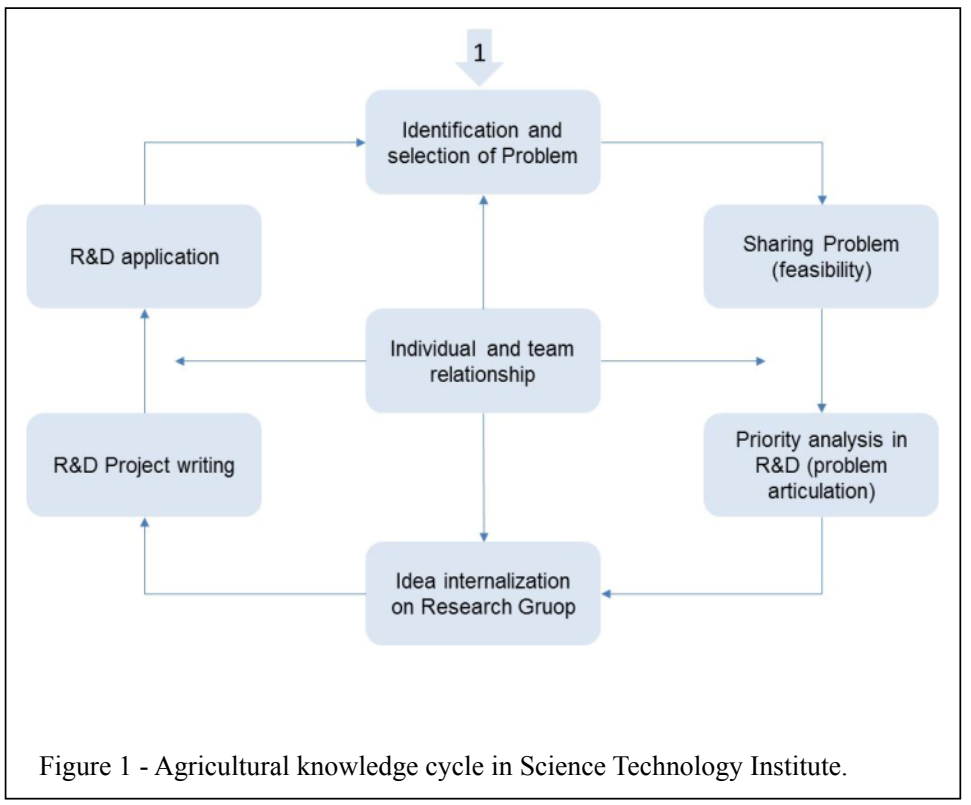

dimensions described in this study, identifying the characteristics of knowledge generation model in agricultural science and technology institutes. Based on the model of NONAKA \& TAKEUCHI (1997), knowledge generation in the agricultural research sector has as fundamental aspects the systemic character and the multidisciplinary interaction, because of the typical factors involved in the sector, such as soil conditions, temperature and other climatic factors, typical for agriculture.

Therefore, the dimension capturing involves opportunities arising from $R \& D$ projects, the demand from farmers, public and private call for proposal, induction from high-management as well as problems arising from poor technology applicability. The dimension internalization involves interaction with team colleagues, farmers, universities, supervisors, project leaders and interpersonal skills. Sharing dimension involves presentation in seminars, articulation with internal and external partners and proposals for research projects.

Regarding lessons and organizational best practices for knowledge generation among scientists and of these with research institutions, it was observed that the knowledge capture is the practice of open innovation described by Chesbrough (2012) who suggests that companies can and should use external knowledge and ideas in the same way they use internal ideas, which is summarized in figure 2 .

\section{CONCLUSION}

As a general view, it was observed that knowledge generation in agriculture originates from ideas, that is, in capturing ideas on how to solve a problem by applying the developed technological competence through a research project. In other areas of knowledge, academic discussion of knowledge management model includes steps to generate, coordinate, externalize, save and, above all, protect the knowledge as a competitive advantage for the company and its value chain.

In agricultural research, knowledge generation begins even before the research project, with the generation of ideas and search for information; traversing the network of relationships among actors and institutions. Communication in scientific media provides opportunity for new applications of the knowledge generated and delivers value to the end-user through food safety/quality, quantity and availability, being a nation's competitive advantage.

The agricultural knowledge generation model appropriates the experiences and knowledge accumulated over time by researchers, through interaction, creating a community, becoming a source of information. The new information and communications technology increasingly enable 


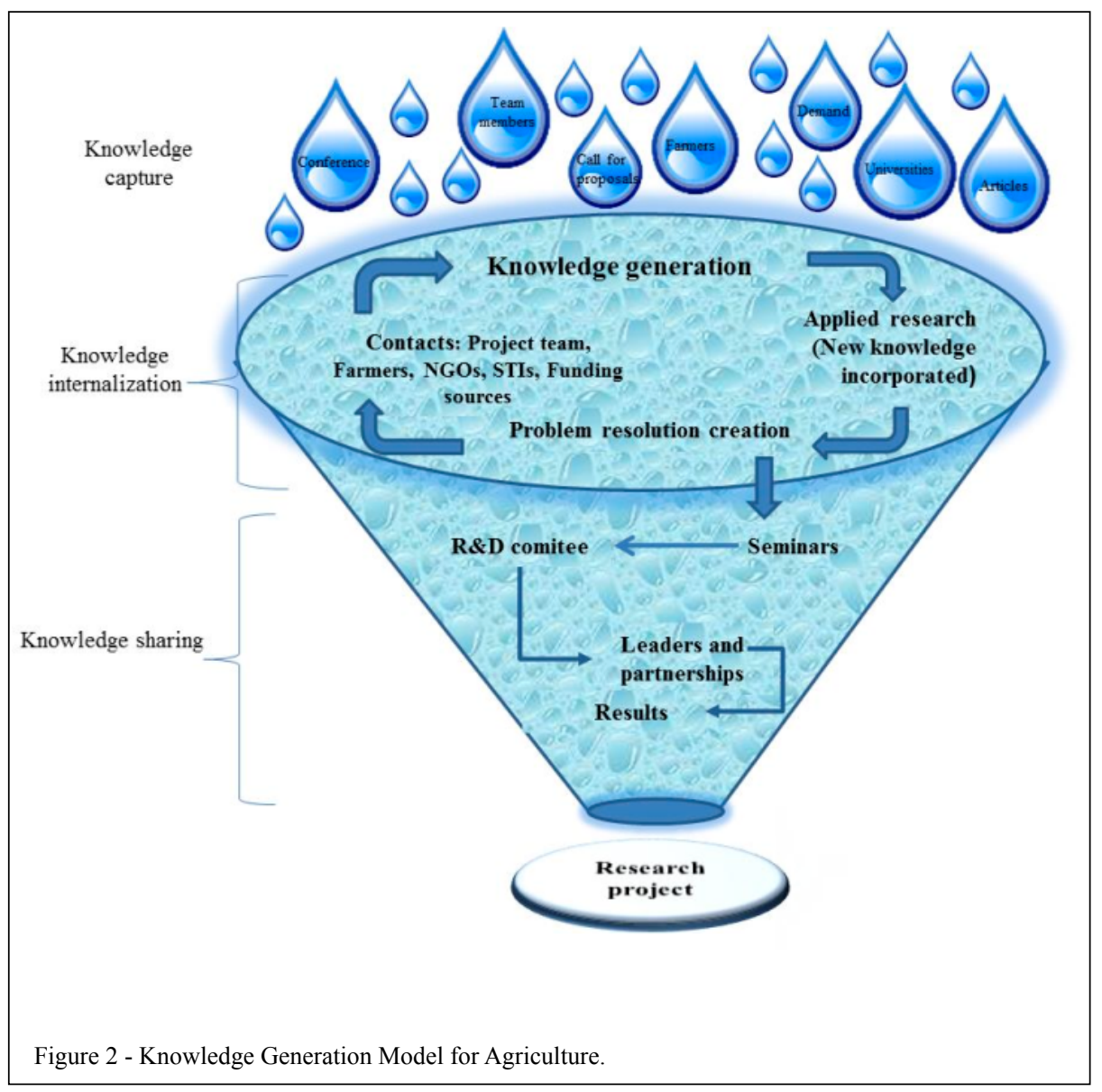

access to remote sources of information, what accelerates the implementation of new discoveries and contributes to the effectiveness of research, development and innovation -RD\&I- in the sector.

Thus, the creation of basic conditions for research and access to information sources an adequate infrastructure is a facilitating of knowledge generation, a necessary condition to be revisited. These conditions include the provision of technical and financial resources; cooperation and articulation agreements with other institutions; continuous training of teams through participation in conferences, fairs and meetings with farmers.

Extend the conceptual model identified in this research is a suggestion for future research to the different actors in the value chain, i.e., scientists, farmers, universities, research institutes, agroindustries, examining the impact of the knowledge generation and the degree of transfer achieved by the technological solution created.

\section{ACKNOWLEDGEMENTS}

To the Universidade Municipal de São Caetano do Sul and the Institutes of Science and Technology: Embrapa, Animal Science Institute - IZ and Instituto Agronômico do Paraná - IAPAR for their support to this research.

\section{SOURCES AND MANUFACTURES}

*Tacit is the knowledge that the individual has acquired over time by living experience, usually difficult to be formalized or explained, being inherent to a person's skills.

"Explicit is the formal and systematic knowledge, expressed by numbers, words, shared in the form of data and models, therefore, theorized.

\section{REFERENCES}

AAKER, D.A.et al. Pesquisa de marketing. 2.ed. São Paulo: Atlas, 2007. p.745.

BELL, M.; PAVITT, K. The development of technological capabilities. In: HAQUE. Trade, technology and 
International Competitiveness. Washington: The World Bank, 1995. V. 1. Chap. 4, p.69-102.

BARROS, J.R.M. O passado e o presente: a visão do economista In: BUAINAIN, A.M.et al.(Org.). O mundo rural no Brasil do século 21: a formação de um novo padrão agrário e agrícola. Brasília, DF: Embrapa, 2014. Prefácio, p. 13 - 19.

CHESBROUGH, H. Inovação aberta: como criar e lucrar com a tecnologia. Tradução: Luiz Claudio de Queiroz Farias. Porto Alegre: Bookman, 2012. p.241.

DALKIR, K. Knowledge management in theory and practice. Burlington, MA: Elsevier, 2005. p.372.

HAIR Jr., J.F.et al. Análise multivariada de dados. 6. ed. Porto Alegre: Bookman, 2009. p.679.
GIL, A. C. Como elaborar projetos de pesquisa. São Paulo: Atlas, 2010. p.184.

NONAKA I; TAKEUCHI, H. Criação de conhecimento na empresa: como as empresas japonesas geram a dinâmica da inovação. 4.ed. Rio de Janeiro: Campus, 1997. p.358.

NONAKA I.et al. Managing flow: teoria e casos de empresas baseadas no conhecimento. Porto Alegre: Bookman, 2011. p.304.

ROSSETTI, A.G. Um modelo conceitual de gestão do conhecimento para unidades organizacionais de pesquisa agropecuária sob a ótica da interdisciplinaridade. 2009. 259f. Tese (Doutorado em Engenharia de Produção) - Universidade Federal de Santa Catarina, SC.

TAKEUCHI, H.; NONAKA I. Gestão do conhecimento. Porto Alegre, RS: Bookman, 2008. p.320. 